\title{
A synthesis on cave-dwelling spiders in Europe
}

\section{Mammola, Stefano}

2018-08

Mammola , S , Cardoso , P , Ribera , C , Pavlek, M \& Isaia, M 2018 , ' A synthesis on cave-dwelling spiders in Europe ' , Journal of Zoological Systematics and Evolutionary Research , vol. 56 , no. 3 , pp. 301-316 . https://doi.org/10.1111/jzs.12201

http://hdl.handle.net/10138/321648

https://doi.org/10.1111/jzs.12201

unspecified

acceptedVersion

Downloaded from Helda, University of Helsinki institutional repository.

This is an electronic reprint of the original article.

This reprint may differ from the original in pagination and typographic detail.

Please cite the original version. 


\section{A synthesis on cave-dwelling spiders in Europe}

3 Stefano Mammola ${ }^{1}$, Pedro Cardoso ${ }^{2}$, Carles Ribera ${ }^{3}$, Martina Pavlek ${ }^{3,4,5}$, Marco Isaia ${ }^{1, *}$

4

5 Authors for correspondence:

6 * marco.isaia@unito.it; phone 0116704544

7 1. Department of Life Sciences and Systems Biology, University of Torino, Turin, Italy

8 2. Finnish Museum of Natural History, University of Helsinki, Helsinki, Finland

9 3. Biodiversity Research Institute and Department of Animal Biology, University of

10 Barcelona, Barcelona, Spain

11 4. Ruđer Bošković Institute, Zagreb, Croatia

12 5. Croatian Biospeleological Society, Zagreb, Croatia

Running title: European cave spiders checklist 


\section{Abstract}

30 We provide the first overview on spiders living in subterranean habitats in Europe,

31 including the first European subterranean spider checklist. In Europe there are 486 spider

32 species known to dwell in caves and other subterranean habitats, distributed across 22

33 families. Despite a few species being able to colonize caves across the whole continent,

34 approximately $90 \%$ of the species show a restricted distribution, occurring exclusively in

35 one or two countries. From a biogeographic perspective, Southern Europe emerges as the

36 main hot spot of subterranean spider diversity, showing the highest richness of endemic

37 species. Compared to other temperate regions of the world, some families appear to be

38 well represented and other poorly represented (or lacking) in European subterranean

39 habitats. Overall, it appears that the taxonomical knowledge on subterranean spiders in

40 Europe is sufficient, but not evenly distributed. As this checklist represents a useful

41 baseline for advances in this field, we point out specific areas of interest for future 42 research. 


\section{I. INTRODUCTION}

44 Following the description of the first blind cave-dwelling vertebrate Proteus anguinus

45 (Amphibia, Proteidae) (Laurenti 1768) and the first cave-obligate invertebrate Leptodirus

46 hochenwartii (Coleoptera, Leiodidae) (Schmidt 1832), interest in subterranean biology

47 gradually increased (Camacho 1992). Soon after the birth of modern spelebiology, Jørgen

48 Schiödte (1812-1884), Emil Racoviţă (1868-1947) and René Jeannel (1879-1965)

49 recognized the potential of cave ecosystems, defining them as ideal settings in which to

50 find evidence for the Darwinian evolution theories, and where to investigate biogeographic

51 patterns of species diversification. These early insights allowed scientists to consider

52 caves ideal ecological and evolutionary laboratories (Poulson and White 1969).

53 From an evolutionary perspective, a breadth of studies focused on morphological and

54 physiological adaptations to the subterranean environment, on cryptic species diversity in

55 caves and on speciation processes (reviewed in Proudlove and Wood 2003; Porter et al.

56 2007; Culver and Pipan 2009a; 2015; Juan et al. 2010; Wilkens 2010). However, the role

57 of caves as ecological laboratories is as yet not fully explored, especially when considering

58 macroecological and biogeographic patterns at a continental or global scale (reviewed in

59 Culver et al. 2013). Theoretically, the subterranean domain gathers accumulated

60 convergent adaptations in filtered subsamples of regional species pools (e.g., Gibert and

61 Deharveng 2002; Derkarabetian et al. 2010; Protas and Jeffery 2012; Fišer et al. 2013; Liu

62 et al. 2017). It has been suggested that the factors driving the biogeographic patterns of

63 phylogenetic distant taxa should also be convergent (Culver et al. 2013), which often

64 allows the generalization of results obtained from a single group of subterranean

65 organisms to other taxa. In spite of that, the analysis of patterns and processes of

66 biological diversity and diversification in subterranean environments is very incomplete for

67 a number of reasons. Foremost, compared with epigean habitats, caves and other 
68 subterranean habitats constitute challenging working environments, making it difficult to

69 assemble a suitable amount of data (Culver et al. 2006; 2013; Zagmajster et al. 2010;

70 Christman et al. 2016; Mammola and Leroy 2017). Secondly, in most regions all

71 troglobionts are invertebrates, fungi or bacteria, invariably underrepresented in ecology

72 and conservation studies (Cardoso et al. 2011); on the other hand, the paucity of species,

73 compared with epigean communities, can make it simpler to understand how subterranean

74 communities assemble and function. Furthermore, whilst state-of-art synthesis for certain

75 cave-dwelling taxa have been published in recent years (e.g. Vanderwolf et al. 2013;

76 Falasco et al. 2015; Du Preez et al. 2017; Mammola and Isaia 2017a), overviews on most

77 subterranean arthropods are still missing.

78 Araneae (spiders) is a very diverse group of arthropods comprising nearly 47,000 extant

79 (World Spider Catalog-WSC, 2017) and nearly 1,300 fossil (Dunlop et al. 2016)

80 described species. According to available approximations, worldwide spider species

81 belonging to at least 48 families have representatives underground (Mammola and Isaia

82 2017a). Recent syntheses suggest that the core of this diversity is found in temperate

83 regions (Reddell 2005), although a comparison with tropical regions may be equivocal due

84 to the fact that these areas have not been sufficiently studied, and to the lack of

85 comprehensive works on tropical cave spiders (see Peck 1999; Bloom et al. 2014;

86 Mammola and Isaia 2017a). While Culver and Pipan (2009a) reported about 30 species of

87 eyeless troglobiont tropical spiders, it is likely that a deep survey of taxonomic papers

88 would certainly disclose remarkable levels of diversity. For instance, cave-dwelling species

89 are abundant in tropical pholcids (e.g. Peck 1990; Gertsch and Peck 1992; Machado et al.

90 2011; Yao et al. 2015, 2016), with approximately 40 genera with troglophile species,

91 several genera with troglobionts (e.g. Micropholcus, Ciboneya, Khorata, Pholcus, Uthina), 
92 and at least three genera including entirely eyeless species (Aymaria, Anopsicus,

93 Metagonia) (B. A. Huber, pers. comm. 2017).

94 Morphological and physiological adaptations in subterranean spiders are directly related to

95 progressive or regressive evolution and often include reduction or loss of cuticular

96 pigments, regression or loss of the eyes-apparatus, thinning of the integuments, elongation

97 of legs, heavy spination, reduction of the metabolic rate leading to higher resistance to

98 starvation, alteration of the circadian rhythm, reduction in fecundity, delayed maturity,

99 slower development, and the tendency to lay a smaller number of eggs (reviewed in

100 Mammola and Isaia 2017a). Phylogenetic studies suggest that these troglobiomorphic

101 traits have evolved several times independently in many spider lineages (e.g. Arnedo et al.

102 2007; Ledford et al. 2011).

103 Contrary to other continents, Europe has been sufficiently studied in its subterranean

104 fauna. Although not exhaustive, we provide the first comprehensive checklist of European

105 subterranean species of spiders. Our aims are to: i) synthesize the scientific knowledge on

106 spiders inhabiting caves and other subterranean habitats across Europe and ii) review the

107 current knowledge on their origin and geographic distribution. A glossary of the main terms

108 and acronyms related to the subterranean biology adopted in this text is presented in Table 1091.

110

\section{II. HISTORICAL BACKGROUND}

112 The first descriptions of European spiders associated with caves date back to the second

113 half of the eighteenth century, when Clerck (1757) and Scopoli (1763) described some

114 poorly adapted species of Nesticus (Nesticidae), Harpactea (Dysderidae), Metellina

115 (Tetragnathidae) and Holocnemus (Pholcidae). A few decades later, Latreille (1804)

116 described the troglophile Meta menardi (Tetragnathidae), from specimens collected in 
117 caves '[...] de la ville du Mans' in the Loire region (France). The latter species is well

118 known among cavers as a ubiquitous cave-dweller in the twilight zone of most European

119 caves.

120 The description of the first troglobiont spider was published in 1857, when Jørgen Matthias

121 Christian Schiödte (1812-1884) described Stalita taenaria (Dysderidae) from the Postojna

122 cave in Slovenia. According to the original description, S. taenaria shows some marked

123 troglobiomorphic traits, being eyeless_'oculi nulli'_and fully depigmented-'abdomine 124 niveo' (Schiödte 1847: 80).

125 These early insights into the subterranean habits of spiders were followed by several 126 descriptions of cave-dwelling species across Southern Europe (e.g., Keyserling 1862; 127 Simon 1872; Pavesi 1873; Simon 1881) (Figure 1). A significant leap forward in the 128 number of described European species is due to the French arachnologist Eugène Simon 129 (1848-1924), who named numerous cave adapted species-especially in the genus 130 Troglohyphantes (Simon 1884) —in his famous book "Les arachnides de France".

131 The beginning of the twentieth century saw a significant increase in European 132 spelobiological studies (Camacho 1992). During his entire career, Simon provided 58 valid 133 descriptions of cave-dwelling species (Simon 1901, 1907, 1910, 1911, 1914, 1929). Along 134 with Simon, the French speleobiologist Jean Baptiste Louis Fage (1883-1964) focused on 135 a variety of cave spider genera (Fage 1912, 1913, 1919, 1945), describing 27 valid 136 species and providing important insights on their origin and adaptations (Fage 1919, 137 1931). Concurrently, the diversity of subterranean spiders was being disclosed by 138 Władysław Jan Kulczyński (1854-1919) and Josef Kratochvíl (1909-1992) in the Balkans 139 (Kulczyński 1914; Kratochvíl 1934, 1935, 1936, 1938, 1939, 1948) and by Ludovico di 140 Caporiacco (1901-1951), Edouard Dresco (1907-2001) and Carl Friedrich Roewer (1881- 
141 1963) in Italy (e.g. Caporiacco 1936, 1938, 1939, 1941; Dresco 1949, 1954, 1956, 1959;

142 Roewer, 1931, 1953).

143 In the second half of the twentieth century, Christa L. Deeleman-Reinhold and Paolo

144 Marcello Brignoli (1942-1986) described numerous European cave-dwelling species and

145 published some important syntheses on their origin and distribution (e.g., Brignoli 1970,

146 1971; Deeleman-Reinhold 1977, 1981). Subsequently, Carles Ribera and Christo

147 Deltshev, among others, focused mostly on the fauna of the lberian and the Balkan 148 peninsulas (Ribera 1978, 2008, 2011; Deltshev 1979, 1988, 2004).

149 From the 1980s onward, subterranean spiders have been discovered in habitats other

150 than caves (Novak et al. 2012; Mammola et al. 2016c). In particular, subterranean spiders

151 have been collected extensively in the deep strata of taluses in central Europe (Rủžička

152 1990, 1996; Růžička and Thaler 2002; Růžička and Klimeš 2005; Laška et al. 2011;

153 Rendoš et al. 2012, 2013; Růžička and Dolanský 2016) and in Milieu Souterrain

154 Superficiel (MSS) across the Iberian Peninsula (e.g., Ortuño et al. 2013; Jiménez-Valverde

155 et al. 2015), Romania (Nae and llie, 2004; Nae, 2008) and Bulgaria (Deltshev et al. 2011).

156 These independent discoveries testified the natural occurrence of subterranean spiders in

157 the network of fissures (screes, rock cracks, etc.), the size of which is not commensurable

158 with the human scale (Culver and Pipan 2009b, 2014; Mammola et al. 2016c).

159 In the last few years, several new species have been described in southern Europe (e.g.,

160 Isaia and Pantini 2008, 2010; Wang and Li 2010a, 2011; Deltshev and Ćurčić 2011;

161 Gasparo 2011; Ribera and López-Pancorbo 2011; Bosmans and Gasparo 2015; Ribera 162 and Mas 2015; Mammola et al. 2016b; Wu et al. 2016; Isaia et al. 2017; Pavlek and Ribera 163 2017), including the first European record of Symphytognathidae (Cardoso and Scharff 164 2009). Studies on European subterranean spiders continues to gain momentum and it is 165 reasonable to expect that new species will be discovered in the future, as proven by the 

167 (Figure 1).

168

accumulation curve of species descriptions, which is far from reaching the asymptote

\section{THE CHECKLIST OF EUROPEAN SUBTERRANEAN SPIDERS}

We relied on the online taxonomic resources on spiders (Nentwig et al. 2017; WSC 2017) and the associated literature data in order to compile the checklist of the European subterranean spiders. In the absence of detailed information on the epigean/hypogean distribution and the natural history of the taxa of interest (Trajano and Carvalho 2017), we based the ecological classification of species(troglobionts or troglophiles as defined in Table 1) on troglobiomorphic traits reported in the original description of each species. When available, ecological information was also considered. We acknowledged that in many circumstances boundaries between categories can be vague; however, we intended to provide a general indication of the degree of subterranean adaptation of European spiders, which can be useful to delineate general patterns and considerations.

Regarding the countrywide distribution of each species, we relied on Nentwig et al. (2017), whereas we derived the global distribution from the WSC (2017). We included all European countries, as defined in Spiders of Europe (Nentwig et al. 2017). However, we excluded the Azores, Madeira, and Canary Islands from the checklist as their insularity leads to different processes which shape regional diversity.

The comprehensive checklist is reported in the Supporting information Table S1. Overall, we identified 195 troglobiont (Figure 2) and 291 troglophile species (Figure 3), distributed altogether in 92 genera across 22 families (Table 2). A number of these species are poorly described, given that many descriptions (ca. 60 species) are based on a single sex and/or lack diagnostic illustrations. 
191 Around $90 \%$ of European cave spiders show a restricted distribution, being found

192 exclusively in one country. The remaining 10\% have a more widespread distribution, 193 ranging across multiple countries. At least three cave-dwelling species are alien to Europe

194 (see section V).

\section{BIOGEOGRAPHY OF SUBTERRANEAN SPIDERS}

198 Although modern biogeographical studies on subterranean spiders based on statistic

199 inference are virtually absent, previous authors made some contributions on the matter,

200 focusing on the general species-distribution patterns in Europe (e.g., Brignoli 1970, 201 1971a,b, 1972, 1973; Deeleman-Reinhold 1978, 1981; Deeleman-Reinhold and Deeleman 202 1980; Deltshev 1978, 2011; Koponen 1993; Ribera and Juberthie 1994; Gasparo and 203 Thaler 2000; Ribera 2004; Cardoso 2012a).

204 The diversity of subterranean spiders is unevenly distributed in Europe (Figure 4). It has 205 been suggested that past climatic events of biogeographical importance played the most 206 important role in determining the European pattern of subterranean spider biodiversity.

207 Traditionally, the theory of relicts and refuges, or climate relict hypothesis (Holsinger 1988;

208 Botosaneanu and Holsinger 1991), has been used to explain subterranean radiation in 209 temperate regions (reviewed in Culver and Pipan 2010). This theory suggests that long-

210 term climatic changes, in particular the Pleistocene glaciations (1.806-0.011 Mya),

211 prompted the colonization of the subterranean habitat and caused the obliteration of

212 surface-dwelling populations. The dramatic impacts due to ice masses north of the Alps

213 and the Carpathians (Holdhaus 1932; see paleo-reconstructions in Ehlers et al. 2011)

214 explain the low diversity of troglobiont spiders at northern latitudes (Růžička et al. 2013).

215 Accordingly, spider faunal assemblages in Northern Europe primarily consist of species 
216 showing minor exaptations to the subterranean life, which possibly recolonized the

217 subterranean habitat after the glacial retreat (Růžička 1999; Figure 4a). Many of these 218 species are indeed widely distributed in Europe-e.g. Palliduphantes pallidus (O. Pickard-

219 Cambridge), Meta menardi, Metellina merianae (Scopoli), Nesticus cellulanus (Clerck) and 220 Porrhomma convexum (Westring) — reaching northern latitudes up to Fennoscandia and 221 the Arctic circle (e.g., Hippa and Koponen 1988; Koponen 1993; Fritzén and Koponen 222 2011). According to different authors (Ransy and Dethier 2006; Carter et al. 2010), the only 223 troglobiomorphic spider found at northern latitudes is Porrhomma rosenhaueri (L. Koch), 224 with scattered records from across central and eastern Europe (e.g. Thaler and Plachter 225 1983; Ransy and Dethier 2006; Růžička et al. 2011, 2013; Staudt et al. 2013; Nentwig et 226 al. 2017).

227 Meanwhile, glaciation cycles prompted the migration of cold-adapted species in Southern 228 Europe and simultaneously shaped the distribution of several preexistent troglobiont 229 species in the Alps and the Pyrenees, which survived in refugial areas found in the 230 periphery of the ice shields. For instance, this pattern is well exemplified by 231 troglobiomorphic species of Troglohyphantes in the Alps, occurring almost exclusively in 232 areas devoid from glaciers (Mammola et al 2015; Mammola et al. 2017a). On the other 233 hand, glacial dynamics fail to elucidate the diversity of troglobiomorphic species of 234 Dysderidae, Nesticidae and Leptonetidae in the Mediterranean basin, such as in the 235 Balkans, southern Italy, southern Iberian Peninsula and most Mediterranean islands. Other 236 climatic events, such as the Messinian Salinity Crisis (Culver and Pipan, 2010), seem to be 237 responsible for having driven the speciation process.

238 In general, biogeographic factors alone appear insufficient to explain the European pattern 239 of diversity. For instance, Culver et al. (2006) demonstrated the existence of a mid-latitude 240 ridge of high subterranean diversity in Europe, which is likely related to long-term surface 
241 productivity. Thus, a higher surface productivity would parallel a higher radiation of spiders

242 in subsurface habitats. According to different authors (e.g. Christman and Culver 2001;

243 Niemiller and Zigler 2013), habitat availability-measured as the amount of caves in an

244 area-is also correlated to subterranean species richness. It is evident that highest

245 diversity of troglobiont spiders is concentrated in the karstic regions, which have a more

246 abundant and directly accessible habitat (see Christman and Culver 2001; Christman et al.

247 2005). This pattern is not only very clear, but also remarkable in the Dinarides, one of the

248 most important European karstic hot-spot (Bregović and Zagmajster 2016). However, it

249 remains unclear whether this is a true biological pattern or a sampling artifact (Christman

250 et al. 2016). In addition, the scarcity of studies investigating MSS (Mammola et al. 2016c),

251 as well as the paucity of speleobiological prospections in non-carbonate substrates across

252 Europe, may represent a further problem in determining a general pattern.

253 The majority of troglobiont spiders in Europe show a very restricted distribution range

254 when compared to epigean spiders (Cardoso, 2012). On the other hand, troglophiles

255 generally show wider ranges of distribution (see Supporting information Table S1). In fact,

256 several troglophile spiders are widespread in European caves (Deltshev 2011). These are

257 mostly Linyphiidae (e.g., Palliduphantes pallidus, Porrhomma convexum), Nesticidae [e.g.,

258 Nesticus cellulanus, Kryptonesticus eremita (Simon)] and Tetragnathidae (e.g., Meta

259 menardi, Metellina merianae). Although these species show some subterranean

260 adaptations and are commonly reported in caves, they are also able to disperse outside,

261 colonizing numerous extra-cave habitats with similar microclimatic conditions.

262 Cardoso (2012a) pointed out that spider species richness in caves is orders of magnitude

263 lower than in neighbouring epigean habitats. While associations of troglobiont and

264 troglophile spiders are frequent, the coexistence of multiple troglobionts in the same cave

265 is less common. Some remarkable examples have been documented in Europe, especially 
266 in the Dinarides. For instance, Culver and Sket (2000) reported the presence of 9 arachnid

267 species coexisting in the Postojna-Planina hypogean system in Slovenia, and 10 in the 268 Pestera de la Movile cave in Romania (Culver and Sket 2000).

269 The co-occurrence of two or more congeneric species within a single cave is even rarer,

270 and it is often mediated by niche partitioning. In Alpine Pimoa (Pimoidae), the coexistence

271 of species was observed for the troglophiles $P$. delphinica and $P$. graphitica, with

272 individuals of the two species sharing the same caves and showing evidence of

273 interspecific gene flow (Mammola et al. 2016b). There are some cases of Porrhomma

274 (Linyphiidae) coexisting in the same cave or MSS (e.g., Růžička 1990; Bedek et al. 2013;

275 Růžička and Dolanský 2016). Furthermore, the presence of two congeneric

276 Troglohyphantes has been recorded in a few caves in Slovenia, Croatia (Deeleman-

277 Rehinold 1978), and in the Western Italian Alps (Isaia and Pantini 2010; Isaia et al. 2011,

278 2017). Typically, the co-occurrence of more species of Troglohyphantes occurs exclusively

279 between phylogenetically distant lineages with different degrees of troglomorphism (Isaia 280 et al. 2017).

\section{V. TAXONOMIC ACCOUNT}

284 Such as other cave-dwelling taxonomic groups (Gibert and Deharveng 2002),

285 subterranean spiders represent filtered subsamples of regional species pools. However, 286 with the notable exception of the Iberian Peninsula (Cardoso 2012a), the extent of the 287 epigean/hypogean community turnover has never been determined.

288 Currently, 63 families of spiders have been reported in Europe (Nentwig et al. 2017; Figure 289 5), of which circa one third has representatives underground, either troglophiles or 290 troglobionts (Figure 6). The taxonomic disharmony in European cave species 
291 assemblages is reflected, among other examples, by the lack of cave-adapted

292 Mygalomorphs. Mygalomorphs are represented in Europe by three families of trap-door 293 spiders (Ctenizidae, Nemesiidae, Cyrtaucheniidae), with the addition of a few species of

294 Theraphosidae. Tentatively, Mygalomorphs are among the largest European spiders, a

295 factor that may have hindered their adaptation to energy-poor environments. Moreover, it

296 is likely that many caves lack appropriate substrates in which to dig burrows. Conversely,

297 in other world regions various species of cave Mygalomorphs have been reported 298 (Mammola and Isaia, 2017a), especially in the tropics (e.g. Bertani et al. 2013; Maroquín 299 2014; Fonseca-Ferreira et al. 2017), where energy inputs in caves are generally higher.

300 Unsurprisingly, families mostly relying on sight for preying, such as active and ambush 301 hunters (e.g. Lycosidae, Oxyopidae, Salticidae and Thomisidae), are also lacking in 302 European caves as well as in the rest of the world (Mammola and Isaia 2017a). Notable 303 exceptions are three species of eyeless Lycosidae, two in Hawaii (Gertsch 1973a) and one 304 in French Polinesia (Framenau and Lehtinen 2014). In addition, it has been suggested that 305 an active lifestyle is not a good adaptation to cave life, as it requires much energy 306 compared to a sit-and wait strategy (e.g. Cardoso 2012a). An exception is found in 307 Dysderidae which, despite displaying an active hunting lifestyle, are particularly diversified 308 in Southern European caves and Shallow Subterranean Habitats (SSHs) (e.g., Deeleman309 Reinhold and Deeleman 1988; Gasparo and Thaler 2000; Arnedo et al. 2007; Cardoso 310 2012a; Macías-Hernández et al. 2016).

311 In comparison to other temperate regions, in European subterranean habitats some 312 families are well represented while others are not. A clear example can be found in the 313 family Dictynidae, which had notable radiations in the North American (e.g. Paquin and 314 Dupérré 2009; Hedin 2015) and Asian karstic areas (e.g. Li and Wang 2017), while they 315 are almost lacking in European subterranean habitats. 
316 Conversely, the Dysderidae, Leptonetidae, Linyphiidae, and Nesticidae-including most

317 European troglobionts-are ubiquitously found across karstic areas in southern Europe 318 and other temperate regions worldwide (e.g., Brignoli 1970; Gertsch 1974, 1984; Lehtinen

319 and Saaristo 1980; Miller 2005; Reddell 2005; Ledford et al. 2011, 2012; Lin et al. 2016).

320 The Dysderidae are renowned for their occurrence in subterranean habitats and include

321 numerous troglobionts, especially in the Dinaric karst and in the Iberian Peninsula (e.g.,

322 Deeleman-Reinhold \& Deeleman, 1988; Gasparo \& Thaler, 2000). Troglobiont-rich genera

323 include Dysdera, Folkia, Harpactea, Mesostalita, Minotauria, Parastalita, Rhode,

324 Speleoharpactea, Stalagtia, and Stalita.

325 The Linyphiidae include numerous species associated with caves and several troglobionts 326 in the genus Antrohyphantes (Balkan peninsula), Centromerus (Iberian Peninsula, Italy, 327 Balkans), Lepthyphantes (Iberian Peninsula, Romania), Palliduphantes (Balkans, Italy, 328 Spain), Troglohyphantes (Alps, Balkans, Cantabrian Mountains, Carpathian, Pyrenees),

329 and Typhlonyphia (Dalmatia). The genus Troglohyphantes, in particular, is the European

330 spider taxon that underwent the largest radiation in caves (Deeleman-Rehinold 1978;

331 Deltshev 2008; Isaia et al. 2011, 2017). It currently includes 127 species (WSC, 2017), of

332 which at least 72 are troglobionts.

333 Leptonetidae are commonly found in subterranean habitats across the Mediterranean 334 basin (Brignoli 1970). Most of the species are troglophiles, but troglobionts can be found in 335 France (Leptoneta), Iberian Peninsula (Teloleptoneta and Leptoneta), Italy 336 (Protoleptoneta), and the Balkan Peninsula (Barusia, Cataleptoneta, Leptonetela, and 337 Sulcia).

338 Nesticidae are renowned for their hypogean adaptations, being often found in underground 339 ecosystems in the Mediterranean basin (Ribera et al. 2014). Troglobiont-rich genera 340 include Carpathonesticus, Kryptonesticus, Nesticus and Typhlonesticus, the latter 
341 consisting exclusively of troglobionts. Notably, in Europe both Leptonetidae and Nesticidae

342 appear to be more diverse in subterranean than in epigean habitats (Figure 6).

343 Hahniidae, Liocranidae, Pholcidae, Agelenidae, Telemidae and Symphytognathidae also

344 include a number of troglobionts. Hahniidae include a few anophtalmic species in the

345 genus Hahnia and Iberina, which are found in the Pyrenees, Romania and Caucasus.

346 Troglobiomorphic Liocranidae are found in the genus Agroecina (Romania) and

347 Cybaeodes (Sicily and Iberian Peninsula). Other troglobionts are found in Agelenidae

348 (Hadites and Histopona) and Pholcidae (Stygopholcus and Hoplopholcus).

349 The troglobiont spiders listed so far belong to genera (or at least families) sharing the

350 same geographic area with congeneric surface-dwelling species. This pattern suggests

351 that, from a phylogenetic point of view, most European cave species did not originate from

352 deep, ancient cladogenetic events. Exceptions are found in Telemidae and

353 Symphytognathidae, which are monospecific in Europe. For this reason, Telema tenella

354 Simon (Telemidae) and Anapistula ataecina (Symphytognathidae) are considered the only

355 true relict species in European caves, ancient representatives of families with tropical 356 origins which once occupied Europe (Fage 1931; Cardoso and Scharff 2009). T. tenella is

357 found in the Oriental Pyrenees and in the province of Gerona (Juberthie 1985; Ribera and

358 Mateos 2000; Wang et al. 2012). Worldwide, the genus Telema consists of an additional

35939 species, found in Guatemala (Gertsch 1973b) and East- and Southeast-Asia (WSC,

360 2017), including several cave-dwelling representatives (e.g., Zu and Chen 2002; Chen and

361 Zu 2009; Lin et al. 2009, Wang and Li 2010b; Zhang and Li 2014). A. ataecina was

362 recently discovered in few caves of the Frade cave system in Portugal (Cardoso and

363 Scharff 2009). The genus includes subterranean species from Western Australian caves

364 (e.g., Harvey 1998). 
365 Finally, at least three cave-associated species are alien to Europe, namely Psilochorus 366 simoni (Berland) (Pholcidae), Nesticella mogera (Yaginuma) and Eidmannella pallida 367 (Emerton) (Nesticidae) (Nentwig 2015; Mammola 2017; Nentwig et al. 2017). P. simoni is 368 native to North America and it has been introduced in Europe at least once, being now 369 established in several European countries (Fürst and Blandenie 1993; Nentwig et al. 370 2017). It is commonly found in caves and other artificial habitats, especially mines 371 (Kostanjšek and Ramšak 2005; Isaia et al. 2011). Nesticella spiders are of Asian descent.

372 N. mogera was recently recorded in a few European countries (e.g., Kielhorn 2009; Bielak-

373 Bielecki and Rozwałka 2011; Nentwig et al. 2017). E. pallida is a cosmopolitan species of

374 tropical and subtropical areas, having been accidentally introduced into greenhouses and 375 similar habitats (Nentwig et al. 2017). It is now commonly found in caves and greenhouses 376 of the Madeira, Canary and Balearic Islands and in the southeastern Iberian Peninsula 377 (Ribera, unpublished data). To our knowledge, no studies have been conducted to attest 378 potential negative impacts on native spider communities in caves.

\section{FUTURE LINES OF RESEARCH}

Several questions concerning the biogeography of subterranean spiders in Europe remain mostly unanswered. In this perspective, the checklist of European cave-dwelling spiders 383 herein provided aims at setting a baseline for speleobiological, arachnological and biogeographical studies. We report a number of long-standing questions, hoping to stimulate future research on subterranean spiders.

387 i) Phylogeographical patterns. Research is needed to shed light on the diversification and 388 origin of the European cave fauna and to understand which are the closest extant relatives 389 of cave obligate species. In particular, establishing empirical phylogenetic patterns of cave 
species using broad taxonomic samples_both cave and epigean species-appears to be

391 a promising line of enquiry.

392

393 ii) Ecological drivers of subterranean spiders. It is still unclear whether species richness

394 and diversity of subterranean spiders in European subterranean habitats are driven by

395 macro-scale (e.g. latitude, past glacial dynamics, macroclimate) or micro-scale parameters 396 (e.g. geology, cave dimension, trophic resources).

398 iii) Functional groups. In terms of foraging guilds (sensu Cardoso et al. 2011), a functional

399 disharmony is often observed in cave-dwelling spiders, with entire guilds being scarcely

400 represented, if not absent, in caves. With the exception of the Iberian Peninsula (Cardoso, 401 2012) there are, however, no studies on functional assemblages of subterranean spider 402 communities.

404 iv) Competition and niche partitioning. Being top-predators, several species of spiders 405 compete with each other for space and resources in subterranean habitats. In Europe, it 406 has been demonstrated that, at a local scale, there is competition between congeneric 407 Meta spiders (Mammola and Isaia 2014), in M. menardi and Metellina merianae (Bourne 408 1976, 1977; Novak et al. 2010) and in M. menardi and Pimoa graphitica (Mammola et al. 409 2016a). However, further studies have to be conducted to better understand how 410 competition between cave-dwelling spiders influences the large scale distribution, 411 especially in high dispersal troglophile species (Mammola et al. 2015; Mammola and Isaia, 412 2017b). 
414 v) Other interspecific relationships. According to Culver and Pipan (2009a), the peculiar

415 conditions found in subterranean habitats limit the risk of predation. However, other

416 asymmetrical interspecific interactions, such as parasitoidism (e.g. Dipterans and

417 Hymenopterans) and parasitism (e.g. fungi and other pathogens), have been rarely

418 investigated. Moreover, the effect of interspecific relationships on distributional patterns

419 (e.g. overlap between parasites/parasitoids and their hosts) has never been considered.

421 vi) Effects of future climate change on distribution patterns. Climatic-driven changes in the 422 distribution range of most subterranean species have been seldom studied (e.g., 423 Brandmayr et al. 2013; Brandmayr and Pizzolotto 2016; Sánchez-Fernández et al. 2016;

424 Mammola and Leroy 2017). Regarding spiders, significant latitudinal shifts are expected 425 within high dispersal species (Mammola 2017; Mammola and Isaia 2017b). On the other 426 hand, contractions in the distribution range can be expected within most restricted 427 cryophilic taxa (Mammola et al. 2017a). Ecological hypotheses about the effect of climate 428 change on organisms dwelling in stable habitats, such as caves, represent a challenging 429 and fast-moving field of research.

431 vii) Assessing the conservation status of subterranean spiders. The status of conservation 432 of most subterranean spiders is unknown, given that a few species have been assessed 433 according to the IUCN criteria (Cardoso 2010; Cardoso and Hilton-Taylor 2015; IUCN 434 2017; Borges et al. 2016; Mammola et al. 2017b; Cardoso et al. 2017). Of these, most 435 assessments are now outdated, having been made before the adoption of the current 436 criteria in 2001, and thus not comparable with the current criteria. Therefore, there is an 437 urgent need for IUCN assessments of European subterranean species and the 
438 development of specific conservation programmes (Martín et al. 2010; Borges et al. 2012;

439 Cardoso et al. 2011, 2016, 2017; Cardoso 2012b; Mammola and Isaia 2017a).

\section{VIII. CONCLUSIONS}

442 In a recent review on the status of biodiversity studies in subterranean habitats, Culver and

443 colleagues argued that (2013:49) "[...] perhaps the time is right for a large-scale global 444 assessment of subterranean biodiversity". With respect to subterranean spiders, we 445 believe that the current paucity of information on the distribution of most species446 especially in the tropics-delays global understanding of their diversity and its thorough 447 comparison across different biogeographic areas. On a more positive note, this work 448 demonstrates that information found in literature can be extracted and summarized in 449 order to provide a reliable baseline to unravel biogeographic patterns-at least in areas 450 where the subterranean fauna is relatively well documented. This is also possible thanks 451 to the extensive online spider taxonomic catalogues (Nentwig et al. 2017; WSC 2017), with 452 current nomenclature, updated synonymies, associated literature and distributional data453 however, such data is currently missing for most large arthropod orders and classes. 454 Although most macroecological questions about subterranean spiders are still 455 unanswered, there is a strong potential for fast advancements in our understanding of their 456 diversity patterns, processes and of the evolution of life in caves.

\section{ACKNOWLEDGMENTS}

459 We are grateful to all photographers for sharing their photos of spiders and their habitats460 see captions of Fig. 1 and 2. A special thanks goes to Alexandra Jones for proof-reading 461 our English, and to Bernhard A Huber and Gustavo Hormiga for providing useful 462 comments of earlier versions of the manuscript. We are thankful to Fulvio Gasparo, who 
463 provided an important revision of the Dysderidae included in the checklist.

464

465 CONFLICT OF INTEREST

466 The authors disclose any actual or potential conflict of interest

467

468 SUPPORTING INFORMATION

469 Table S1. Checklist of the European subterranean spiders.

470 


\section{REFERENCES}

472 Arnedo MA, Oromi P, Múrria C, Macías-Hernández N, Ribera C (2007) The dark side of an island radiation:

473 systematics and evolution of troglobitic spiders of the genus Dysdera Latreille (Araneae: Dysderidae) in the

474 Canary Islands. Invertebr Systs 21:623-660.

475

476 Bedek J, Bilandžija H, Bregović P, Jalžić B, Lukić M, Pavlek M (2013) Fauna of the Cave System Đulin ponor

477 - Medvedica. In: Janjann Ž, Vučić V (ed), The Cave System Đulin ponor - Medvedica (Đula' Sinkhole -

478 Medvedica Cave). Caving Guidebook, Ogulin, pp 75.

480 Bertani R, Bichette ME, Pedroso DR (2013) Tmesiphantes hypogeus sp. nov. (Araneae, Therapho-sidae), 481 the first troglobitic tarantula from Brazil. An Acad Bra Ciên 85(1):107-115.

Bielak-Bielecki P, Rozwałka R (2011) Nesticella mogera (Yaginuma, 1972) (Araneae: Nesticidae) in Poland.

Acta Biol 18:137-141.

Bloom T, Binford GA, Esposito L, Garcia GA, Peterson I, Nishida A, Loubet- Senear K, Agnarsson I (2014)

Discovery of two new species of eyeless spiders within a single Hispaniola cave. J Arachnol 42:148-154.

Borges P, Crespo L, Cardoso P (2016) Species conservation profile of the cave spider Turinyphia cavernicola

(Araneae, Linyphiidae) from Terceira Island, Azores, Portugal. Biodiv Data J 4:e10274.

493 Borges PAV, Cardoso P, Amorim IR, Pereira F, Constância JP, Nunes JC, Barcelos P, Costa P, Gabriel R and

494 Dapkevicius MdL (2012) Volcanic caves: priorities for conserving the Azorean endemic troglobiont species.

495 Int J Speleol 41(1):101-112.

497 Bourne JD (1976) Notes préliminaires sur la distribution spatiale du Meta menardi, Triphosa dubitata,

498 Triphosa sabaudiata, Nelima aurantiaca et Culex pipiens au sain d'un écosystéme cavernicole (Grotte de 499 Scierce: Mte. Savoie). Int J Speleol 8:253-267. 
501 Bourne JD (1977) Mise en evidence de groupements temporaires de la faune pariétale dans un tunnel

502 ertificiel en fonction de l'humidité et des mouvements d'air. Rev Suis Zool 84:527-539.

503

504 Brandmayr P, Pizzolotto R (2016) Climate change and its impact on epigean and hypogean carabid beetles.

505 Period biol 118(3): 147-162.

506

507 Brandmayr P, Giorgi F, Casale A, Colombetta G, Mariotti L, Taglianti AV, Weber F, Pizzolotto R (2013)

508 Hypogean carabid beetles as indicators of global warming? Environ Res Lett 8:1-11.

510 Bregović P, Zagmajster M (2016) Understanding hotspots within a global hotspot - identifying the drivers of 511 regional species richness patterns in terrestrial subterranean habitats. Insect Conserv Divers 9:268-281.

513 Brignoli PM (1970) Considerazioni biogeografiche sulla famiglia Leptonetidae (Araneae). Bull Mus Nat Hist 514 Natur Paris 41:189-195.

516 Brignoli PM (1971a) Note su ragni cavernicoli italiani (Araneae). Fragm Entomol 7:129-229.

518 Brignoli PM (1971b) Considerazioni biogeografiche sui ragni cavernicoli Mediterranei. Acta V Arachnological 519 Congress (Brno, 1971):79-84.

521 Brignoli PM (1972) Catalogo dei ragni cavernicoli italiani. Quad Circ Speleol Rom 1:1-212.

523 Bosmans R, Gasparo F (2015) A new cave-dwelling Centromerus from Sardinia (Araneae: Linyphiidae).

524 Fragm Entomol 46:113-116.

526 Botosaneanu L, Holsinger J (1991) Some aspects concerning colonization of the subterranean realm -

527 especially subterranean waters: a response to Rouch and Danielopol, 1987. Stygologia 6:11-39. 
529 Camacho Al (1992) The natural history of biospeleology. Monographs of the National Museum of Natural

530 Sciences Madrid: National Museum of Natural Sciences.

531

532 Caporiacco L di (1936) Aracnidi cavernicoli della provincia di Verona. Le Grotte d'Italia, Trieste 1:1-10.

534 Caporiacco L di (1938) Un nuovo Troglohyphantes delle grotte piemontesi. Le Grotte d'Italia, Trieste 2:4253543.

537 Caporiacco L di (1939) Aracnidi cavernicoli delle Puglie. Le Grotte d'Italia, Trieste 3:43-47.

539 Caporiacco L di (1941) Aracnidi cavernicoli bresciani. Le Grotte d'Italia, Trieste 4:82-90.

541 Cardoso P (2010) Anapistula ataecina. The IUCN Red List of Threatened Species, e.T176265A7207415.

543 Cardoso P (2012a) Diversity and community assembly patterns of epigean vs. troglobiont spiders in the 544 Iberian Peninsula. Int J Speleol 41:83-94.

546 Cardoso P (2012b) Habitats Directive species lists: urgent need of revision. Insect Conserv Divers 5(2):169547174.

549 Cardoso P, Hilton-Taylor C (2015) Nothophantes horridus. The IUCN Red List of Threatened Species, $550 \quad$ T70560176A70560214.

552 Cardoso P, Scharff N (2009) First record of the spider family Symphytognathidae in Europe and description 553 of Anapistula ataecina sp. n. (Araneae). Zootaxa 2246:45-57. 
555 Cardoso P, Erwin TL, Borges PAV, New TR (2011) The seven impediments in invertebrate conservation and

556 how to overcome them. Biol Conserv 144:2647-2655.

557

558 Cardoso P, Stoev P, Georgiev T, Senderov V, Penev L (2016) Species Conservation Profiles compliant with

559 the IUCN Red List of Threatened Species. Biodiv Data J 4:e10356.

560

561 Cardoso P, Crespo L, Silva I, Borges P, Boieiro M (2017) Species conservation profiles of endemic spiders

562 (Araneae) from Madeira and Selvagens archipelagos, Portugal. Biodiv Data J 5:e20810.

563

564

565 Carter J, Fowles A, Angele C (2010) Monitoring the population of the linyphid spider Porrhomma rosenhaueri

566 (L. Koch, 1872) (Araneae: Linyphiidae) in Lesser Garth Cave, Cardiff, UK. J Cave Karst Sc 37:3-8.

568 Chen HM, Zhu MS (2009) Two new troglobitic species of the genus Telema (Araneae, Telemidae) from

569 Guizhou, southwestern China. J Nat Hist 43: 1705-1713.

570

571 Christman MC and Culver DC (2001) The relationship between cave biodiversity and available habitat. J

572 Biogeogr 28:367-380.

574 Christman MC, Culver DC, Madden MK, White D (2005) Patterns of endemism of the eastern North

575 American cave fauna. J Biogeogr 32:1441-1452.

576

577 Christman MC, Doctor DH, Niemiller ML, Weary DJ, Young JA, Zigler K, Culver DC (2016) Predicting the

578 occurrence of cave-inhabiting fauna based on features of the earth surface environment. PLoS ONE $579 \quad 11: \mathrm{e} 0160408$.

580 
581 Clerck C (1757) Svenska spindlar, uti sina hufvud-slågter indelte samt under några och sextio särskildte arter

582 beskrefne och med illuminerade figurer uplyste. Stockholmiae.

583

584 Culver DC, Deharveng L, Bedos A, Lewis JJ, Madden M, Reddell JR, Sket B, Trontelj P, White D (2006) The 585 mid-latitude biodiversity ridge in terrestrial cave fauna. Ecography 29: 120-128.

586

587 Culver DC, Pipan T (2009a) The Biology of Caves and Other Subterranean Habitats. Oxford: Oxford

588 University Press.

590 Culver DC, Pipan T (2009b) Superficial subterranean habitats - gateway to the subterranean realm? J Cave

591 Karst Sc 35:5-12.

592

593 Culver DC, Pipan T (2010) Climate, abiotic factors, and the evolution of subterranean life. Acta Carsol 594 39:577-586

595

596 Culver DC, Pipan T (2014) Shallow Subterranean Habitats: Ecology, Evolution, and Conservation.

597 Amsterdam: Elsvier.

599 Culver DC, Pipan T (2015) Shifting paradigms of the evolution of cave life. Acta Carsol 44: 415-425.

600

601 Culver DC, Sket B (2000) Hotspots of subterranean biodiversity in caves and wells. J cave Karst St 62:1160217.

603

604 Culver DC, Trontelj P, Zagmajster M, Pipan T (2013) Paving the way for standardized and comparable 605 subterranean biodiversity studies. Subt Biol 10:43.

606 
607 Deeleman-Reinhold CL (1977) Distribution patterns in European cave spiders. Congrès International de

608 Spéléologie 7:25-34.

609

610 Deeleman-Reinhold CL (1978) Revision of the cave-dwelling and related spiders of the genus

611 Troglohyphantes Joseph (Linyphiidae), with special reference to the Jugoslav species. Op Acad Sc Art Slov $612 \quad 23: 1-221$.

613

614 Deeleman-Reinhold CL (1981) Remarks on origin and distribution of troglobitic spiders. Proceedings of the 8 615 international congress of speleology:305-308.

616

617 Deeleman-Reinhold CL, Deeleman PR (1980) Remarks on troglobitism in spiders. Proceedings of the 8 618 Internationaler Arachnologen-Kongress Wien: 433-438.

620 Deeleman-Reinhold CL, Deeleman PR (1988) Revision des Dysderinae (Araneae, Dysderidae), les especes 621 mediterraneennes occidentales exceptees. Tijdschr entomol 131:141-269.

623 Deltshev C (1978) The Origin, formation and zoogeography of Troglobitic spiders of the Balkan Peninsula.

624 Proceedings of the 7th International Congress of Arachnology (Exeter, 1977) 42:345-351.

626 Deltshev C (2008) Faunistic diversity and zoogeography of cave-dwelling spiders on the Balkan Peninsula.

627 Advances in Arachnology and Developmental Biology, papers dedicated to Prof. Dr. Božidar Ćurčić.

628 monographs 12:327-348.

630 Deltshev C (2011) The faunistic diversity of cave-dwelling spiders (Arachnida, Araneae) of Greece. Arachnol 631 Mitteil 40:23-32.

632

633 Deltshev C, Ćurčić BPM (2011) A new spider species Harpactea complicata Deltshev sp. nov. from caves of 634 Serbia (Araneae: Dysderidae). Zootaxa 2782:34-38. 
636 Deltshev C, Lazarov C, Naumova C, Stoev C (2011) A survey of spiders (Araneae) inhabiting the euedaphic

637 soil stratum and the superficial underground compartment in Bulgaria. Arachnol Mitteil 40:33-46.

638

639 Derkarabetian S, Steinmann DB, Hedin M (2010) Repeated and time-correlated morphological convergence

640 in cave-dwelling harvestmen (Opiliones, Laniatores) from montane western North America. PLoS ONE $641 \quad 5: e 10388$.

642

643 Dresco E (1949) Note sur les araignées de quelques grottes de l'Italie méridionale et description d'une 644 espèce nouvelle. Boll Soc Nat Napoli 58:1-6.

646 Dresco E (1954) Description d'une araignée cavernicole nouvelle du genre Paraleptoneta. Notes biospéol $647 \quad 9: 45-48$.

648

649 Dresco E (1956) Tegenaria henroti, espèce nouvelle des grottes de Sardaigne (Araneae, Agelenidae).

650 Fragm Entomol 2:115-119

651

652 Dresco E (1959) Tegenaria zinzulusensis, araignée nouvelle d'Italie du sud (Araneae, Agelenidae). Bull du 653 Mus Nat Hist Natur Paris 31:506-509.

654

655 Du Preez G, Majdi N, Swart A, Traunspurger W, Fourie H (2017) Nematodes in caves: a historical

656 perspective on their occurrence, distribution and ecological relevance. Nematology, doi:10.1163/1568541165700003068

658 
659 Dunlop JA., Penney D, Jekel D (2016) A summary list of fossil spiders and their relatives. In: World Spider

660 Catalog, version 17.5. Natural History Museum Bern. Available at http://wsc.nmbe.ch. Accessed on

$661 \quad 29.09 .2016$.

662

663 Ehlers J, Gibbard PL, Hughes PD (2011) Quaternary glaciations - extent and chronology. A closer look (Vol.

664 15). Amsterdam, Elsvier.

665

666 Fage L (1912) Etudes sur les araignées cavernicoles. I. Revision des Ochyroceratidae (n. fam.).

667 Biospelogica, XXV. Arc Zool Expér Génér 5:97-162.

668

669 Fage L (1913) Etudes sur les Araignées cavernicoles. II. Revision des Leptonetidae. Biospelogica, XXIX. Arc

670 Zool Expér Génér 10:479-576.

671

672 Fage L (1919) Etudes sur les araignées cavernicoles. III. Sur le genre Troglohyphantes. Biospelogica XL. Arc

673 Zool Expér Génér 58:55-148.

674

675 Fage L (1931) Biospeologica LV; Araneae; précédée d'un essai sur l'Evolution souterraine et son

676 déterminisme. Arc Zool Expér Génér 5:99-291.

677

678 Fage L (1945) A propos de quelques araignées cavernicoles de Crète. Mus Nat Hist Natur Paris 17:109-114.

679

680 Falasco E, Ector L, Isaia M, Wetzel CE, Hoffmann L, Bona F (2014) Diatom flora in subterranean

681 ecosystems: a review. Int J Speleol, 43: 231-251.

682

683 Fišer C, Zagmajster M, Zakšek V (2013) Coevolution of life history traits and morphology in female

684 subterranean amphipods. Oikos 122:770-778.

685 
686 Fonseca-Ferreira R, de Almeida Zampaulo R, Leite Guada JP (2017) Diversity of iron cave-dwelling 687 mygalomorph spiders from Pará, Brazil, with description of three new species (Araneae). Tropical zool $68830(4): 178-199$.

689

690 Framenau VW, Lehtinen PT (2014) Nukuhiva Berland, 1935 is a troglobitic wolf spider (Araneae: Lycosidae), 691 not a nursery-web spider (Pisauridae). Zootaxa 4028:129-135.

692

693 Fritzén NR, Koponen S (2011) The cave spider Meta menardi (Araneae, Tetragnathidae) occurrence in

694 Finland and notes on its biology. Mem Soc pro Fauna Flora Fenn 87:80-86.

695

696 Fürst PA, Blandenier G (1993) Psilochorus simoni (Berland, 1911)(Araneae, Pholcidae): Découvertes de 697 nouvelles stations suisses et discussion de son écologie. Bulletin de la Société neuchâteloise des Sciences 698 naturelles 116:75-85.

699

700 Gasparo F (2011) Una nuova Harpactea cavernicola di Creta (Araneae, Dysderidae). Atti Mem Comm Gr "E. 701 Boegan" 43: 57-65.

702

703 Gasparo F, Thaler K (2000) I ragni cavernicoli del Venezia Giulia (Italia nord-orientale) (Arachnida, Araneae). 704 Atti Mem Comm Gr "E. Boegan" 37:17-55.

Gertsch WJ (1973a) The cavernicolous fauna of the Hawaiian lava tubes. 3. Areaneae (Spiders). Pacific Ins 707 $16: 415-426$.

709 Gertsch WJ (1973b). A report on cave spiders from Mexico and Central America. AMCS Bull 5: 141-163.

711 Gertsch WJ (1974) The spider family Leptonetidae in North America. J Arachnol 1:145-203. 
713 Gertsch WJ (1984) The spider family Nesticidae (Araneae) in North America, Central America, and the West 714 Indies. Bull Texas Mem Mus 31: 1-91.

716 Gertsch WJ, Peck SB (1992) The pholcid spiders of the Galápagos Islands, Ecuador (Araneae, Pholcidae).

717 Can J Zool 70: 1185-1199.

718

719 Gibert J, Dehrveng L (2002) Subterranean ecosystems: a truncated functional biodiversity. Bioscience $720 \quad 52: 473-481$.

722 Harvey MS (1998) A review of the Australasian species of Anapistula Gertsch (Araneae:

723 Symphytognathidae). Rec Wes Aus Mus 19:111-120.

725 Hedin M (2015) High- stakes species delimitation in eyeless cave spiders (Cicurina, Dictynidae, Araneae)

726 from central Texas. Mol Ecol 24:346-361.

728 Hippa H, Koponen S (1988) The arthropod fauna of Gronligrotta, Norway. Cave Science 15:117-119.

730 Holsinger JR (1988) Troglobites: the evolution of cave-dwelling organisms. Am Sci 76:147-153.

732 Holdhaus K (1932) Die europäische Höhlenfauna in ihren Beziehungen zur Eiszeit. Zoogeographica 1:1-32.

734 Isaia M, Pantini P (2008) A new species of Troglohyphantes (Araneae, Linyphiidae) from the western Italian 735 Alps. J Arachnol 35:427-431.

737 Isaia M, Pantini P (2010) New data on the spider genus Troglohyphantes (Araneae, Linyphiidae) in the Italian 738 Alps, with the description of a new species and a new synonymy. Zootaxa 2690:1-18. 
740 Isaia M, Paschetta M, Lana E, Pantini P, Schonhofer AL, Christian E, Badino G (2011) Subterranean

741 arachnids of the Western Italian Alps (Arachnida: Araneae, Opiliones, Palpigradi, Pseudoscorpiones). Torino,

742 Monografie del Museo di Scienze Naturali.

744 Isaia M, Mammola M, Mazzuca P, Arnedo MA, Pantini, P (2017) Advances in the systematics of the spider 745 genus Troglohyphantes (Araneae, Linyphiidae). Syst Biodiv 15: 307-326.

IUCN (2017) The IUCN Red List of Threatened Species. Available online at: http://www.iucnredlist.org.

749 Jiménez-Valverde A, Gilgado JD, Sendra A, Pérez-Suárez G, Herrero-Borgoñón JJ, Ortuño VM (2015)

750 Exceptional invertebrate diversity in a scree slope in Eastern Spain. J Ins Conserv 19:713-728.

752 Juan C, Guzik MT, Jaume D, Cooper SJ (2010) Evolution in caves: Darwin's 'wrecks of ancient life' in the 753 molecular era. Mol Ecol 19:3865-3880.

755 Juberthie C (1985) Cycle vital de Telema tenella dans la Grotte-Laboratoire de Moulis et strategies de 756 reproduction chez les Araignees cavernicoles. Mém Biospéol 12:77-89.

758 Juberthie C, Decou V (1994) Structure et diversité du domaine souterrain; particularités des habitats et 759 adaptations des espèces. Encyclopaedia Biospeologica 1:5-22.

761 Keyserling E (1862) Beschreibung einer neuen Spinne aus den Hohlen von Lesina. Verhandlungen der

762 Kaiserlich-Königlichen Zoologisch-Botanischen Gesellschaft in Wien 12:539-544.

764 Kielhorn K-H (2009) First records of Spermophora kerinci, Nesticella mogera and Pseudanapis aloha on the 765 European Mainland (Araneae: Pholcidae, Nesticidae, Anapidae). Arachnol Mitteil 37: 31-34. 
767 Koponen S (1993) On the biogeography and faunistics of European spiders: latitude, altitude and insularity.

768 Bull Soc Neuch Sci Nat 116:141-152.

769

770 Kostanjšek R, Ramšak L (2005) Psilochorus simoni (Berland, 1911)(Araneae, Pholcidae), a new record for

771 Slovenian fauna from Postonjska jama cave. Natura sloveniae 7:37-40.

772

773 Kratochvíl J (1934) Pregled pecinskih paukova u Jugoslaviji. Prirodoslovne Razprave 2:165-226.

774

775 Kratochvíl J (1935) Araignées cavernicoles de Krivošije. Práce Morav Prírodov Spole 9:1-25.

776

777 Kratochvíl J (1936) Nouveau genre d'araignées cavernicoles en Yugoslavie. Typhlonyphia reimoseri n. gen.

778 n. sp. Věst Českosl Zool Společ Praze 3:69-79.

779

780 Kratochvíl J (1938) Étude sur les araignées cavernicoles du genre Sulcia nov. gen. Práce Morav Př́rodov

781 Spole 11:1-25.

782

783 Kratochvíl J (1939) À propos des deux araignées cavernicoles de Yougoslavie. Věst Českosl Zool Společ

784 Praze 6-7:279-289.

785

786 Kratochvíl J (1948) Étude sur les araignées cavernicoles du genre Stygohyphantes gen. nov. Věst Českosl

787 Zool Společ Praze 12:3-24.

788

789 Kulczyński W (1914) Aranearum species novae minusve cognitae, in montibus Kras dictis a Dre C. Absolon

790 aliisque collectae. Bull Int Acad Sc Cracovie 1914:353-387.

791

792 Laška V, Kopecký O, Růžička V, Mikula J, Véle A, Šarapatka B, Tuf IH (2011) Vertical distribution of spiders

793 in soil. J Arachnol 39: 393-398. 
795 Latreille PA (1804) Histoire naturelle générale et particulière des Crustacés et des Insectes. Paris 7:144-305.

797 Laurenti JN (1768) Specimen medicum, exhibens synopsin reptilium emendatum cum experimentis circa 798 venena et antidota reptilium austriacorum. Wien: Joan. Thom. nob. de Trattnern.

800 Ledford J, Paquin P, Cokendolpher J, Campbell J, Griswold C (2011) Systematics of the spider genus

801 Neoleptoneta Brignoli, 1972 (Araneae: Leptonetidae) with a discussion of the morphology and relationships

802 for the North American Leptonetidae. Invertebr Syst 25:334-388.

803

804 Ledford J, Paquin P, Cokendolpher J, Campbell J, Griswold C (2012) Systematics, conservation and 805 morphology of the spider genus Tayshaneta (Araneae, Leptonetidae) in Central Texas Caves. ZooKeys 806 167:1-102.

808 Lehtinen PT, Saaristo M (1980) Spiders of the Orientral-Australian region. II Nesticidae. Annales Zool Fenn $809 \quad 17: 47-66$.

810

811 Li S, Wang X (2017) New cave-dwelling spiders of the family Dictynidae (Arachnida: Araneae) from Guangxi 812 and Guizhou, China. Zool Syst 42:125-228.

814 Lin Y, Ballarin F, Li S (2016) A survey of the spider family Nesticidae (Arachnida, Araneae) in Asia and

815 Madagascar, with the description of forty-three new species. ZooKeys 627:1-168.

817 Lin YC, Pham DS, Li SQ (2009) Six new spiders from caves of northern Vietnam (Araneae: Tetrablemmidae:

818 Ochyroceratidae: Telemidae: Symphytognathidae). Raffles B Zool 57: 323-342 
820 Liu W, Golovatch S, Wesener T, Tian M (2017) Convergent evolution of unique morphological adaptations to

821 a subterranean environment in cave millipedes (Diplopoda). PLoS ONE 12:e0170717.

822

823 Machado A de B, Ribera C (1986) Araneidos cavernicolas de Portugal: Familia Leptonetidae (Araneae).

824 Actas X Congreso Internacional de Aracnologia Barcelona 1:355-366.

825

826 Machado EO, Ferreira RL, Brescovit AD (2011). A new troglomorphic Metagonia Simon 1893 (Araneae,

827 Pholcidae) from Brazil. Zootaxa 3135: 59-62.

828

829 Macías-Hernández N, López SC, Roca-Cusachs M, Oromí P, Arnedo MA (2016) A geographical distribution

830 database of the genus Dysdera in the Canary Islands (Araneae, Dysderidae). ZooKeys 625: 11-23.

831

832 Mammola S (2017) Modelling the future spread of native and alien congeneric species in subterranean habitats - the case of Meta cave-dwelling spiders in Great Britain. Int J Speleol 46(3):427-437.

835 Mammola S, Isaia M (2014) Niche differentiation in Meta bourneti and M. menardi (Araneae, Tetragnathidae)

836 with notes on the life history. Int J Speleol 43:343-353.

838 Mammola S, Isaia M (2016) The ecological niche of a specialized subterranean spider. Invertebr Biol $839 \quad 135: 20-30$.

840

841 Mammola S, Isaia M (2017a) Spiders in caves. Proc R Soc Lond B Biol Sci 284: 20170193.

843 Mammola S, Isaia M (2017b) Rapid poleward distributional shifts in the European cave-dwelling Meta 844 spiders under the influence of competition dynamics. J Biogeogr, doi:10.1111/jbi.13087. 
846 Mammola S, Leroy B (2017) Applying species distribution models to caves and other subterranean habitats.

847 Ecography, doi:10.1111/ecog.03464

848

849 Mammola S, Isaia M, Arnedo MA (2015) Alpine endemic spiders shed light on the origin and evolution of

850 subterranean species. PeerJ 3:e1384.

851

852 Mammola S, Piano E, Isaia M (2016a) Step back! Niche dynamics in cave-dwelling predators. Acta Oecol $853 \quad 75: 35-42$

854

855 Mammola S, Hormiga G, Arnedo MA, Isaia M (2016b) Unexpected diversity in the relictual European spiders 856 of the genus Pimoa (Araneae, Pimoidae). Invertebr Syst 30:566-587.

858 Mammola S, Giachino PM, Piano E, Jones A, Barberis M, Badino G, Isaia M (2016c) Ecology and sampling 859 techniques of an understudied subterranean habitat: the Milieu Souterrain Superficiel (MSS). Sc Nat 103:88.

861 Mammola S, Goodacre SL, Isaia M (2017a) Climate change may drive cave spiders to extinction. Ecography $86240: 1-10$.

864 Mammola S, Hormiga G, Isaia M (2017b) Species conservation profile of the stenoendemic cave spider 865 Pimoa delphinica (Araneae, Pimoidae) from the Varaita valley (NW-Italy). Biodiv Data J 5:e11509.

867 Maroquín JIM. 2014. Taxonomic revision of Hemirrhagus Simon, 1903 (Araneae: Theraphosidae, 868 Theraphosinae), with description of five new species from Mexico. Zoological Journal of the Linnean Society. 869 170(4):634-689.

870

871 Martín JL, Cardoso P, Arechavaleta M, Borges PAV, Faria BF, Abreu C, Aguiar AF, Carvalho JA, Costa AC, 872 Cunha RT, Fernandes FM, Gabriel R, Jardim R, Lobo C, Martins AMF, Oliveira P, Rodrigues P, Silva L, 
873 Teixeira D, Amorim IR, Homem N, Martins B, Martins M \& Mendonça E (2010) Using taxonomically unbiased

874 criteria to prioritize resource allocation for oceanic island species conservation. Biodivers Conserv 19:1659-

8751682

876

877 Miller JA (2005) Cave adaptation in the spider genus Anthrobia (Araneae, Linyphiidae, Erigoninae). Zool

878 Scripta 34: 565-592.

879

880 Moseley M (2009) Size matters: scalar phenomena and a proposal for an ecological definition of 'cave'.

881 Cave and Karst Science 35:89-94.

882

883 Nae A, llie V (2004) Data concerning the spider diversity (Arachnida: Aranenae) from the Closani karstic area

884 (Oltenia, Romania), with special reference to the superficial subterranean environment. Travaux du Muséum

885 National d'Histoire Naturelle "Grigore Antipa" 47: 31-41.

886

887 Nae A (2008) Data concerning the Araneae fauna from the aninei mountains Karsik Area (Banat, Romania).

888 Trav Inst Speol "Emile Racovitza" 47: 53-63.

889

890 Nentwig W (2015) Introduction, establishment rate, pathways and impact of spiders alien to Europe. Biol Inv $891 \quad 17: 2757-2778$.

892

893 Nentwig W, Blick T, Gloor D, Hänggi A, Kropf C (2017) Spiders of Europe, version 01.2017. Available at

894 www.araneae.unibe.ch. Accessed 06.01.2017. doi: 10.24436/1

895

896 Niemiller ML, Zigler KS (2013) Patterns of cave biodiversity and endemism in the Appalachians and Interior

897 Plateau of Tennessee, USA. PLoS ONE 8:e64177.

898 
899 Novak T, Tkvac T, Kuntner M, Arnett EA, Delakorda SL, Perc M, Janžekovič F (2010) Niche partitioning in

900 orbweaving spider Meta menardi and Metellina merianae (Tetragnathidae). Acta Oecol 36: 522-529.

901

902 Novak T, Perc M, Lipovšek S, Janžekovič F (2012) Duality of terrestrial subterranean fauna. Int J Speleol

$903 \quad 41: 181-188$.

904

905 Ortuño VM, Gilgado JD, Jiménez-Valverde A, Sendra A, Pérez-Suárez G, Herrero-Borgoñón JJ (2013) The

906 "alluvial mesovoid shallow substratum", a new subterranean habitat. PLoS ONE 8:e76311.

907

908 Paquin P, Dupérré N (2009) A first step towards the revision of Cicurina: redescription of type specimens of

90960 troglobitic species of the subgenus Cicurella (Araneae: Dictynidae), and a first visual assessment of their

910 distribution. Zootaxa 2002: 1-67.

911

912 Pavesi P (1873) Sopra una nuova specie di ragni (Nesticus speluncarum) appartenente alle collezione del

913 Museo civico di Genova. Ann Mus Civ St Nat Genova 4: 344-352.

914

915 Pavlek M, Ribera C (2017) Kryptonesticus deelemanae gen. et sp. nov. (Araneae, Nesticidae), with notes on 916 the Mediterranean cave species. Eur J Taxon 262: 1-27.

917

918 Peck SB (1990) Eyeless arthropods of the Galapagos Islands, Ecuador: Composition and origin of the 919 cryptozoic fauna of a young, tropical, oceanic archipelago. Biotropica 22: 366-381.

920

921 Peck SB (1999) Historical biogeography of Jamaica: evidence from cave invertebrates. Can J Zool 77: 368922380.

923

924 Porter LM (2007) Subterranean biogeography: what have we learned from molecular techniques? J Cave 925 Karst Sc 69:179-186. 
927 Poulson TL, White WB (1969) The cave environment. Science 165:971-981.

928

929 Proudlove G, Wood PJ (2003) The blind leading the blind: cryptic subterranean species and DNA taxonomy.

930 Trends Ecol Evol 18:272-273.

931

932 Protas M, Jeffery WR (2012) Evolution and development in cave animals: from fish to crustaceans. Wiley

933 Interdiscip Rev Dev Biol 1:823-845.

934

935 Ransy M, Dethier M (2006) Note sur Porrhomma rosenhaueri (L. Koch, 1872) [Araignée, Linyphiidæ] en

936 Belgique. Bull Cherch Wallonia 45:109-112.

937

938 Reddell JR (2005) Spiders and related groups. In: Culver DC, White WB (ed), Encyclopedia of caves, $2^{\text {nd }}$

939 edition. Amsterdam: Elsvier, pp 786-797.

940

941 Rendoš M, Mock A, Jászay T (2012) Spatial and temporal dynamics of invertebrates dwelling karstic

942 mesovoid shallow substratum of Sivec National Nature Reserve (Slovakia), with emphasis on Coleoptera.

943 Biologia 67:1143-1151.

944

945 Resende LPA, Bichuette ME (2016) Sharing the space: coexistence among terrestrial predators in

946 Neotropical caves. J Nat Hist 50:2107-2128.

947

948 Ribera C (1979) Distribution des Nesticidae cavernicoles de la Péninsule Ibérique. Rev Arachnol 2:291-300.

950 Ribera C (1988) La familia Leptonetidae (Arachnida, Araneae) in la Península lbérica. In: Haupt J (ed), XI

951 Europäisches Arachnologisches Colloquium. Berlin: Technische Universität Berlin Dokumentation Kongresse 952 und Tagungen, 267-281. 
954 Ribera C (2004) Arachnida: Araneae (Spiders). In: Gunn J (ed), Encyclopaedia of Caves and Karst Sciences.

955 Fitzroy Dearborn, Taylor and Francis, pp 71-73.

956

957 Ribera C, Juberthie C (1994) Araneae. In: Juberthie C, Decu V (ed), Encyclopaedia biospeologica. Moulis958 bucarest, pp 197-214.

960 Ribera C, López-Pancorbo A (2011) Nesticus baeticus sp. n., a new troglobitic spider species from south961 west Europe (Araneae, Nesticidae). ZooKeys 89: 1-13.

963 Ribera C, Mateos E (2000) Telema tenella (Simon, 1882)(Telemidae) y Argyroneta aquatica (Clerck, 1758)

964 (Argyronetidae), dos nuevas familias de araneidos para la fauna ibérica. Rev Iber Aracnol 1: 61-63.

966 Ribera C, Mas ED (2015) Description of three new troglobiontic species of Cybaeodes (Araneae,

967 Liocranidae) endemic to the Iberian Peninsula. Zootaxa 3957:313-323.

968

969 Ribera C, Elverici M, Kunt KB, Özkütük RS (2014) Typhlonesticus gocmeni sp. n., a new cave-dwelling blind 970 spider species from the Aegean region of Turkey (Araneae, Nesticidae). ZooKeys 419:87-102.

972 Roewer CF (1931) Arachnoideen aus südostalpinen Höhlen gesammelt von Herrn Karl Strasser in den

973 Jahren 1929 und 1930. Mitteilungen über Höhlenund Karstforschung 1931:1-17.

975 Roewer CF (1953) Cavernicole arachniden aus Sardinien. Notes biospéologiques 8:39-49.

977 Růžička V (1990) The spiders of stony debris. Acta Zool Fenn 190:333-337.

979 Růžička V (1996) Spiders in stony debris in South Bohemian mountains. Silva Gabreta 1:186-194. 
981 Růžička V (1999) The first steps in subterranean evolution of spiders (Araneae) in Central Europe. J Nat Hist $982 \quad 33: 255-265$.

983

984 Růžička V, Thaler K. 2002) Spiders (Araneae) from Deep Screes in the Northern Alps (Tyrol, Austria). Ber 985 Naturwiss-med Ver Innsb 89:137-141.

986

987 Růžička V, Klimeš L (2005) Spider (Araneae) communities of scree slopes in the Czech Republic. J Arachnol 988 33:280-289.

989

990 Růžička V, Dolanský J (2016) Catching of spiders in shallow subterranean habitats in the Czech Republic.

991 Arachnol Mitteil 51:43-48.

992

993 Růžička V, Laška V, Mikula J, Tuf IH (2011) Morphological adaptations of Porrhomma spiders inhabiting soil. 994 J Arachnol 39: 355-357.

995

996

997 Růžička V, Šmilauer P, Mlejnek R (2013) Colonization of subterranean habitats by spiders in Central Europe. 998 Int J Speleol 42:133-140.

999

1000 Sánchez-Fernández D, Rizzo V, Cieslak A, Faille A, Fresneda J, Ribera I (2016) Thermal niche estimators 1001 and the capability of poor dispersal species to cope with climate change. Sci Rep 6:23381.

1003 Schiödte JC (1847) Forelöbig Beretning om Untersögelser om den underjordiske Fauna i Hulerme i Krain og 1004 Istrien. Oversigt over det Kongelige Danske Videnskabernes Selskabs Forhandlinger, pp 75-81. 
1006 Scopoli JA (1763) Entomologia carniolica, exhibens insecta carniolae indigena et distributa in ordines, 1007 genera, species, varietates. Methodo Linnaeana. Vindobonae 420:392-404.

1008

1009 Simon E (1872) Notice complémentaire sur les arachnides cavernicoles et hypogés. Ann Soc Entomol 1010 France (5)2:473-488.

1011

1012 Simon E (1881) Arachnides nouveaux ou peu connus des provinces basques. Anal Soc Esp Hist Nat 1013 10:127-132.

1014

1015 Simon E (1884) Les arachnides de France. Paris 5:180-885.

1016

1017 Simon E (1901) Note sur les arachnides capturés par M. Mazauric dans la grotte de Trabuc (Garde). Bull 1018 Soc Entomol France 1901: 238-239.

1019

1020 Simon E (1907) Araneae, Chernetes et Opiliones (Première série). Biospeologica. III. Arch Zool Expér Génér 1021 (4)6:537-553.

1022

1023 Simon E (1910) Araneae et Opiliones (Seconde Série). Biospeologica. XV. Arch Zool Expér Génér (5)5:49102466.

1025

1026 Simon E (1911) Araneae et Opiliones (Troisième série). Biospeologica. XXIII. Arch Zool Expér Génér 1027 (5)9:177-206.

1028

1029 Simon E (1914) Les arachnides de France. Synopsis générale et catalogue des espèces françaises de 1030 I'ordre des Araneae; 1re partie. Paris 6:1-308.

1031

1032 Simon E (1929) Les arachnides de France. Synopsis générale et catalogue des espèces françaises de 1033 l'ordre des Araneae; 3e partie. Paris 6:533-772. 
1035 Staudt A, Weber D, Nährig D (2013) Webspinnen (Arachnida, Araneae) aus Höhlen des Grossherzogtums 1036 Luxemburgs. Ferrantia 69: 115-157

1038 Sket B (2008) Can we agree on an ecological classification of subterranean animals? J Nat Hist 42:154910391563

1040

1041 Thaler K, Plachter H (1983) Spinnen aus Höhlen der Fränkischen Alb, Deutschland (Arachnida: Araneae:

1042 Erigonidae, Linyphiidae). Senckenb Biol 63: 249-263.

1043

1044 Trajano E, Carvalho MR de (2017) Towards a biologically meaningful classification of subterranean 1045 organisms: a critical analysis of the Schiner-Racovitza system from a historical perspective, difficulties of its 1046 application and implications for conservation. Subt Biol 22:1-26.

1047

1048 Vanderwolf K, Malloch D, McAlpine DF, Forbes GJ (2013) A world review on fungi, yeasts, and slime molds 1049 in caves. Int J Speleol 42:77-96.

1050

1051 Wang CX, Li SQ (2010a) Two new species of the spider genus Cataleptoneta from Balkan Peninsula 1052 (Araneae, Leptonetidae). Zootaxa 2730:57-68.

1053

1054 Wang CX, Li SQ (2010b) New species of the spider genus Telema (Araneae, Telemidae) from caves in 1055 Guangxi, China. Zootaxa 2632: 1-45.

1056

1057 Wang CX, Li SQ (2011) A further study on the species of the spider genus Leptonetela (Araneae:

1058 Leptonetidae). Zootaxa 2841:1-90.

1059

1060 Wang C, Ribera C, Li SQ (2012) On the identity of the type species of the genus Telema (Araneae,

1061 Telemidae). ZooKeys 251:11-19.

1062

1063 Wilkens H (2010. Genes, modules and the evolution of cave fish. Heredity 105:413-422. 
1065 World Spider Catalog (2017) World Spider Catalog, version 17.5. Natural History Museum Bern. Available at 1066 http://wsc.nmbe.ch. Accessed 06.01.2017. doi: 10.24436/2

1067

1068 Wu Y, Wang C, Zheng G, Li S (2016) Three new species of the genus Leptonetela from Greece (Araneae, 1069 Leptonetidae). ZooKeys 569: 23-35.

1070

1071 Yao Z, Pham DS, Li S (2015) Pholcid spiders (Araneae: Pholcidae) from northern Vietnam, with descriptions 1072 of nineteen new species. Zootaxa 3909: 1-82.

1073

1074 Yao Z, Dong T, Zheng G, Fu J, Li S (2016). High endemism at cave entrances: a case study of spiders of the 1075 genus Uthina. Sci Rep 6: 35757.

1076

1077 Zagmajster M, Culver DC, Christman MC, Sket B (2010) Evaluating the sampling bias in pattern of 1078 subterranean species richness: combining approaches. Biodiv Cons 19: 3035-3048.

1079

1080 Zhang Y, Li S (2014) A spider species complex revealed high cryptic diversity in South China caves. Mol 1081 phylog evol 79: 353-358.

1082

1083 Zhu MS, Chen HM (2002) A new cave spider of the genus Telema from China (Araneae: Telemidae). Acta 1084 Zoot Sinica 27: 82-84.

1085 
TABLES

1087 Table 1. Definition of main terms and acronyms related to the subterranean biology

1088 adopted in this text.

\begin{tabular}{|c|c|c|c|}
\hline Term & Acronym & Definitions adopted herein & Reference(s) \\
\hline Troglobiomorphism & - & $\begin{array}{l}\text { The complex of morphological and } \\
\text { physiological adaptations to the } \\
\text { subterranean environmental } \\
\text { conditions. }\end{array}$ & Juberthie and Decu 1994 \\
\hline Troglobiont & TB & $\begin{array}{l}\text { An organism strictly bound to the } \\
\text { hypogean habitat, clearly exhibiting } \\
\text { subterranean adaptations. }\end{array}$ & \multirow{3}{*}{ Sket 2008} \\
\hline Troglophile & TF & $\begin{array}{l}\text { Organisms which are able to maintain } \\
\text { stable subterranean populations } \\
\text { (eutroglophile) or are inclined to } \\
\text { inhabit subterranean habitats, being } \\
\text { however intimately associated with } \\
\text { epigean habitats for some biological } \\
\text { functions (subtroglophile). }\end{array}$ & \\
\hline Trogloxene & - & $\begin{array}{l}\text { An epigean species occurring } \\
\text { accidentally underground. }\end{array}$ & \\
\hline $\begin{array}{l}\text { Shallow_or Superficial- } \\
\text { Subterranean Habitats }\end{array}$ & SSH & $\begin{array}{l}\text { The aphotic subterranean habitats } \\
\text { close to the surface, harboring } \\
\text { species with troglobiomorphic traits, } \\
\text { namely hypotelminorheic habitats, } \\
\text { epikarst, lava tubes, deep leaf litter, } \\
\text { deep soil strata and the MSS. }\end{array}$ & Culver and Pipan 2009b, 2014 \\
\hline Milieu Subterrain Superficiel & MSS & $\begin{array}{l}\text { A terrestrial SSH represented by the } \\
\text { underground network of empty air- } \\
\text { filled voids and cracks harboring } \\
\text { species with troglobiomorphic traits. }\end{array}$ & Mammola et al. 2016c \\
\hline
\end{tabular}




\begin{tabular}{|c|c|c|c|c|c|}
\hline \multirow[b]{2}{*}{ Family } & \multicolumn{2}{|c|}{$\begin{array}{l}\text { Hypogean } \\
\text { elements }\end{array}$} & \multicolumn{2}{|c|}{$\begin{array}{l}\text { Total in } \\
\text { Europe }\end{array}$} & \multirow[b]{2}{*}{ Notes } \\
\hline & Gen. & Sp. & Gen. & Sp. & \\
\hline Agelenidae & 5 & 40 & 19 & 220 & Mainly troglophiles. Troglobionts in Histopona and Hadites. \\
\hline Amaurobiidae & 1 & 3 & 4 & 39 & Some troglophiles in Amaurobius. \\
\hline Anapidae & 2 & 3 & 3 & 5 & Some weakly adapted species in MSS habitats. \\
\hline Cybaeidae & 1 & 1 & 4 & 15 & Cybaeus vignai is the only species showing troglobiomorphic traits. \\
\hline Dictynidae & 3 & 4 & 19 & 69 & $\begin{array}{l}\text { Some troglophile species in the genus Cicurina, Chorizomma and } \\
\text { Mastigusa. }\end{array}$ \\
\hline Dysderidae & 16 & 56 & 22 & 372 & $\begin{array}{l}\text { Many troglobiont species mostly distributed in the Mediterranean } \\
\text { basin. }\end{array}$ \\
\hline Filistatidae & 1 & 1 & 3 & 11 & Filistata insidiatrix often at the cave entrance. \\
\hline Hahniidae & 2 & 3 & 8 & 34 & Troglobionts in Hahnia and Iberina. \\
\hline Leptonetidae & 8 & 60 & 8 & 69 & Numerous genera with troglophiles and troglobionts. \\
\hline Linyphiidae & 28 & 222 & 217 & 1231 & $\begin{array}{l}\text { Several troglobiont-rich genera (e.g. Centromerus and } \\
\text { Troglohyphantes). }\end{array}$ \\
\hline Liocranidae & 2 & 5 & 12 & 53 & Troglobionts in Cybaeodes and Agraecina. \\
\hline Mysmenidae & 1 & 1 & 3 & 4 & Trogloneta granulum in bare-colluvial MSS. \\
\hline Nesticidae & 6 & 50 & 7 & 55 & $\begin{array}{l}\text { Different genera, all mostly related to caves. Troglophiles and } \\
\text { troglobionts. }\end{array}$ \\
\hline Pholcidae & 6 & 20 & 12 & 44 & $\begin{array}{l}\text { Mostly troglophiles. Troglobiomorphic species in Hoplopholcus and } \\
\text { Stygopholcus. }\end{array}$ \\
\hline Pimoidae & 1 & 4 & 1 & 4 & Only represented in Europe by the genus Pimoa, troglophile. \\
\hline Segestriidae & 1 & 2 & 2 & 18 & Two species of Segestria found in caves. \\
\hline Sicariidae & 1 & 1 & 1 & 2 & Loxosceles rufescens often associated with caves and other SSH. \\
\hline Sparassidae & 1 & 1 & 5 & 15 & Heteropoda variegata often associated with caves. \\
\hline Symphytognathidae & 1 & 1 & 1 & 1 & $\begin{array}{l}\text { Only represented in Europe by Anapistula ataecina (relict species, } \\
\text { troglobiont). }\end{array}$ \\
\hline Telemidae & 1 & 1 & 1 & 1 & $\begin{array}{l}\text { Only represented in Europe by Telema tenella (relict species, } \\
\text { troglobiont). }\end{array}$ \\
\hline Tetragnathidae & 2 & 3 & 4 & 32 & $\begin{array}{l}\text { Troglophiles in Meta and Metellina, widespread in European } \\
\text { caves. }\end{array}$ \\
\hline Theridiidae & 3 & 5 & 46 & 228 & Troglophile species in Episinus, Robertus and Rugathodes \\
\hline Total (22) & 93 & 486 & 402 & 2522 & See Supporting information Table S1 for the complete checklist. \\
\hline
\end{tabular}


1104 Figure 1. Number of subterranean spider species described from 1757 to 2015.

1106 Figure 2. Examples of the diversity of spiders in European subterranean habitats-

1107 troglobionts. a) Hadites tegenarioides Keyserling (Agelenidae); b) Stalagtia

1108 hercegovinensis (Nosek) (Dysderidae); c) Stygopholcus absoloni (Kulczyński) (Pholcidae);

1109 d) Troglohyphantes sp. (Linyphiidae) e) Stalita pretneri Deeleman-Reinhold (Dysderidae);

1110 f) Sulcia sp. (Leptonetidae)—note the typical violet reflexes on the legs, a useful character

1111 for distinguishing Leptonetidae in the field; g) Typhlonesticus absoloni (Kratochvíl)

1112 (Nesticidae); h) Typhlonyphia sp. (Linyphiidae). Photo credits/by curtesy of: a,d,h: Tin

1113 Rožman; b,c,e,f,g) Martina Pavlek.

1115 Figure 3. Examples of the diversity of spiders in European subterranean habitats1116 troglophiles. a) Loxosceles rufescens (Dufour) (Siicaridae); b) Palliduphantes pallidus (O.

1117 P.-Cambridge) (Linyphiidae); c) Pimoa graphitica Mammola, Hormiga and Isaia

1118 (Pimoidae); d) Nesticus cellulanus (Clerck) (Nesticidae) e) Porrhomma convexum

1119 (Westring) (Linyphiidae); f) Meta menardi (Latreille) (Tetragnathidae); g) Hoplopholcus

1120 labyrinthi (Kulczyński) (Pholcidae); h) Tegenaria sp. (Agelenidae). Photo credits/by curtesy

1121 of: $\mathbf{a}-\mathbf{c}, \mathbf{f}, \mathbf{h}$ : Francesco Tomasinelli (b and $\mathbf{f}$ in Isaia et al. 2011) d: Enrico Lana (in Isaia et

1122 al. 2011); e: Mauro Paschetta (in Isaia et al. 2011); g: Fulvio Gasparo (in Nentwig et al.

1123 2017).

1125 Figure 4. Distribution of troglophilic (a) and troglobitic (b) spiders in Europe. For each 1126 country, shades of grey indicate number of species (see legend). 
1128 Figure 5. Family charts of European spiders and cave-dwelling spiders, with reference to 1129 troglobionts and troglophiles.

1130

$1131 \mathbf{F}$

1132 i

$1133 \mathbf{g}$

$1134 \mathbf{u}$

$1135 \mathbf{r}$

$1136 \mathbf{e}$

1137

11386

1139 .

1140

$1141 \mathrm{P}$

$1142 \mathrm{r}$

$1143 \quad 0$

$1144 \mathrm{p}$

$1145 \quad 0$

$1146 r$

$1147 \quad \mathrm{t}$

$1148 \quad \mathrm{i}$

$1149 \quad 0$

$1150 \mathrm{n}$

1151

11520

$1153 \mathrm{f}$

1154 